\title{
The Impact of Corporate Social Responsibility on Firm's Profitability- a Case Study on Maharatna Companies in India
}

\author{
Dr. Amalendu Bhunia ${ }^{1}$, Lakshmi Das ${ }^{2}$ \\ ${ }^{1}$ Associate Professor, Department of Commerce,University of Kalyani, West Bengal, India \\ ${ }^{2}$ Research Scholar, Department of Commerce, University of Kalyani, West Bengal, India
}

\begin{abstract}
The present research work investigates the impact of corporate sector responsibility on firm's profitability of seven Maharatna Companies in India. In the second decade of the New Century in India, companies are obligatory to expend corporate sector responsibility expenditures so that societies and natural environment of India are improved steadily. Now corporate social responsibility has been considered as a significant factor of profitability because most of the forms' feel that their profitability might be increased for that. This study is based on secondary data obtained from the Annual Reports of the seven Maharatna Companies for the period from 2004 to 2013. To find out the impact corporate sector responsibility on firm's profitability, correlation, simple regression and multiple regression analysis have been used. Empirical results indicate that corporate sector responsibility affect the firm's profitability positively in case Gas Authority of India Ltd. and negatively in case of rest of the companies under study
\end{abstract}

Keywords: Corporate sector responsibility, profitability, Maharatna Company, India, correlation and regression analysis

\section{INTRODUCTION}

Companies are under pressure with a new responsibility across the globe that is to meet up the requirements of the current generation with no compromising the capability of the subsequent generations to meet up their individual requirements. Companies are being implored to obtain accountability for the conduct their actions shock the societies and the natural atmosphere. They are also being inquired to show the insertion of social and environmental anxieties in business processes and in communications with stakeholders (Babalola, 2012). The Corporate Social Responsibility (CSR) thought has exemplarily fascinated the awareness of the business world and researchers. The financial performance of a company is very much reliant on the moral business activities as well as social and environmental assistances. These tricks will facilitate a corporate sector to keep up its repute and benevolence. It is a high time not to detain business organisation merely for firm's profitability however consider the social benefit as financial achievement. However, CSR has a strong association between the company and its stakeholders. CSR activities need accountability on the companies' component in the direction of its stakeholders particularly its employees, employees and society besides the objectives of profit maximization. These actions comprise obligations about environmental fortification, social comforts and on condition that a vigorous and protected working place for its employees (Kiran et al, 2015).

There are so many factors which can affect the financial performance of firm. CSR is one of the important factors for firm's profitability. Both CSR and profitability are like a two way communication i.e. both are correlated to each other. If a firm do CSR activity very satisfactorily then the profitability may improves for that. Another thing is that if firm's profitability improves then firm can further spend much more for CSR activities, before the firm has spent for it. There are so many studies that prove the relationship between CSR and firm's profitability. CSR helps to improves profitability by two ways i.e. by saving energy, waste, maintain, operating etc. On the other hand, with the help of CSR company can improves the relationship with Government, customer loyalty, employees encouragement etc. which may effects firm's profitability indirectly (Jiao and Xie, 2013). With the help CSR, firms not only try to enhance their long term relationship with all stakeholders but also improve their reputation and build up their brand image, which ultimately increases their customer's number. As company can take care of all stakeholders through CSR, company can attract and keep a good number of employees and can provide a suitable working condition

${ }^{1}$ Corresponding Author: bhunia.amalendu@gmail.com 
which leads to improves productivity and ultimately effect the profitability of firms. Another point is that through CSR company may have a good relationship with investors that help to have a huge capital, investment from them.

Now CSR is mandatory in India as per the new Company Act 2013 in Sec. 135, Schedule VII, which has been effected from $1^{\text {st }}$ April 2014. It has been stated that those companies have a net worth of 500 crore or more; or turnover of 1000 crore or more; or net profit of 5 crore or more, have to spend $2 \%$ of their average profit of last three years (put reference). The Department of Public Enterprises also issued a guidelines regarding CSR for the Central Public Sector Enterprises in India on $1^{\text {st }}$ April 2013, in which every Maharatna company have to do CSR activities mandatorily, though it has been seen that every Maharatna company was doing CSR activities before having the new Company Act and the guideline of DPE. As CSR is now mandatory for Maharatna companies, it is important to see how their profitability is affected by CSR at present i.e. after having the new Company Act and the guideline of DPE. Therefore an attempt has taken to investigate the impact of CSR on the financial performance of the Maharatna companies.

\section{LITERATURE REVIEW}

Das and Halder (2011) studied the CSR activities of Oil and Natural Gas Corporation limited (ONGC) and its effect on socio-economic development of rural population in Assam. They have seen that ONGC has a great value and trust among the rural people where all the ONGC projects have been carried out. ONGC has done its social activities in every sphere like infrastructure of buildings, creating employment through training and education, market accessibility needs, improving health, empowering the weaker section of the people. Kanwal et al (2013) investigated the impact of CSR on FP of 15 listed companies in Karachi stock exchange. Using correlation analysis they have founded that CSR and FP have a positive relationship between each other and CSR can increase firm's social value, reputation as well as profitability of firm. Lech (2013) Study the theoretical aspects of CSR and assessed the association between CSR and financial performance that how much CSR positively improves the economic performance from the shareholder's perspective of the largest Polish companies on the Warsaw Stock Exchange for the period of 2010-12. The result showed that there is no statistically significant relationship between CSR and financial performance of Polish firms. Kim et al (2013) attempted to examine the relationship between CSR and financial performance of the Korean stock market. This study showed a positive result i.e. CSR has a positive impact on financial performance of Korean stock market. John et al (2013) investigated the correlation between CSR and firm's financial performance with a sample of 20 Nigerian Manufacturing firms for the year 20022011. By using correlation and regression analysis, they have concluded that there is a significant relationship between CSR and profit before tax and turnover. They have remarked to increase investment in CSR activities to have a better financial performance in long run in Nigerian Manufacturing companies. Mwangi and Jerotich (2013) examined the bonding between CSR and financial performance using multiple regression analysis. They also studied what type of CSR activities have been taken by the manufacturing, construction and allied sector of NSE. They have concluded that there was an insignificant relationship between CSR practices and financial performance and most of the manufacturing, construction and allied sector companies liked to invest much more for community development then the staff welfare then environment and lastly for product and customers. Kumar and Reddy (2014) studied the practices of CSR in SAIL, they concluded that SAIL did not have the CSR policy to carry out CSR activities properly and the unspent amount of CSR budget was reallocated to different plants and units of SAIL rather than to carry on this remaining amount of CSR budget to next year. Gupta and Arora (2014) did a extensive research to study the existing CSR practices executed by Public Sector Enterprises in India. They have taken 5 Maharatna companies and 2 Navaratna companies for the study. They concluded that more or less all Maharatna and Navaratna companies do same type of CSR practices and they are doing a very good job regarding CSR. They recommended that collective effort of Government and private players surly achieve the desire level of CSR activities in companies for the better improvement of society. Shing (2014) examined the impact of CSR disclosure on the financial performance of three industries of UK for the period 2008-12. The result showed that there is no positive impact of CSR disclosure on financial performance of these industries in short period as well as in long period. Ikharehon (2014) investigated the influence of CSR on firm's profitability of eighty six companies in Nigeria for the period 2003-2012. The result showed a negative affiliation between CSR and firm's profitability. The author recommended that awareness of CSR should be increased among various stakeholders and business to understand the necessity and advantages of CSR. He suggested that Government should develop a relevant CSR policy and build up an effective regulatory authority to implement all guidelines of CSR and carry on the progress of CSR. Daniel et al (2014) attempted to study the CSR on financial performance of banking sector of Ghana. They have concluded that though there is a positive link between CSR and financial performance of Ghanaian banking sector, but the financial performance of these banks depends on their controllable variables like growth, origin, debt ratio and size. 
Hirigoyen and Rehm (2014) assessed the causal relationship between the various aspects of CSR (human resource, human rights in work place, societal commitment, respect for environment, market behavior and government) and financial performance (return on equity, return on assets, market to book ratio) of 329 listed companies in U.S. ,Europe and Asia pacific region for the year 2009-10. Using linear regression analysis and Granger Causality test they have seen that CSR does not have any influence on financial performance; furthermore, it is negatively correlated with each other. Ciciretti et al (2014) examined the impact of community responsibilities (which is a part of CSR) of bank on financial performance of banks. They have found a positive impact of CSR on financial performance. Allen (2014) examined the impact of CSR on CFP from the two points of view like consumer and non consumer industry with a sample of 429 firms. By using Time series regression analysis, the author concluded that the relationship between CSR-sales is negative for both consumer and non consumer companies but the relationship between CSR-gross profit is more positive for non consumer companies than consumer companies. Murtaza et al (2014) examined the connection between CSR and CFP of food companies in Pakistan using Nvivo test (qualitative method) and regression analysis (quantitative method). The result showed that there is a positive correlation between CSR and CFP. Pan et al (2014) assessed the relationship between CSR and Corporate Financial Performance (CFP) of 288 Chinese mineral listed firms from 2010-2013 by using Pooled Least Square Regression analysis. They have considered CSR issues in five different sub issues and out of them shareholder responsibility, employee responsibility, supplier, customer responsibility have significant relationship with CFP. But there is no relationship between the public responsibility and CFP. They have pointed out the differences in the relationship CSR and CFP for five sublevels due to industry characteristics. Ahamed et al (2014) investigated the association between CSR and Corporate Financial Performance (CFP) for Malaysia firm by using regressing analysis. The result showed a positive affiliation between CSR and CFP of Malaysia firm. Iqual et al (2014) examined the impact of CSR and CFP with a sample of twenty six companies listed in KSE by using stakeholder theory for the period from 2008-12. Using Multiple Regression analysis they have concluded that CSR practices have a positive impact on CFP only for few stakeholders. But after adjusting the regression model as per Pakistan scenario, three stakeholders like customer, shareholders and suppliers were considered as main key stakeholder for CSR, those who have an impact on CFP in the firm of Pakistan. Folajin et al (2014) examined the liaison between CSR and the profitability of United Bank of Africa (UBA) for the period of 2006-2012. By using OLS regression model they founded that CSR have a negative impact on bank's profitability in short term but it may have a positive impact on net profit in long run. They recommended that Government should have some policy regarding CSR and build up some mechanism and institutions for the implementation of CSR. Athma and Yarragorla (2015) investigated the major differences between CPSE Guidelines and Sec. 135 of Company Act 2013 along with the impact of CSR as per Sec.135 of new Company Act 2013 on Maharatna Companies for the period from 2011-14. They concluded that CSR liability of Maharatna companies is more or less equal as per both CPSE Guideline and Sec. 135 of company act 2013 and CSR provision of Sec.135 is more flexible than CPSE Guideline regarding CSR. Fu and Shen (2015) examined the connectivity between CSR and financial performance of sixty three food processing Chinese companies with the help of stakeholder's theory. They have concluded a positive relationship CSR and financial performance.

\section{RESEARCH METHODOLOGY}

This study is based on secondary time series yearly data collected from annual reports of the seven Maharatna Central Public Sector Enterprises in India for the period from 2003-04 to 2012-13. Seven Maharatna Central Public Sector Enterprises in India includes Bharat Heavy Electrical Ltd. (BHEL), Coal India Limited (CIL), Indian Oil Corporation Ltd. (IOCL), Gas Authority of India Ltd. (GAIL), Oil Natural Gas Corporation (ONGC), National Thermal Power Corporation (NTPC) and Steel Authority of India Ltd. (SAIL). The present study considers corporate social responsibility expenditures, profit after tax and earnings per share as variables. In the course of analysis, correlation, simple regression and multiple regression test methods have been used. To fulfill the objective, this study considers the following research hypotheses.

$\mathrm{H}_{1}$ : CSR has a significant positive relationship with profits after tax

$\mathrm{H}_{2}$ : CSR has a significant positive relationship with earnings per share

\section{EMPIRICAL RESULTS AND ANALYSIS}

4.1 Empirical Results of BHEL

4.1.1 Correlation Statistics 


\section{American Research Journal of Humanities and Social Sciences, Volume 1, Issue 3, June-2015 ISSN 2378-7031}

In general, correlation statistics makes an effort to detect the extent and trend of connection between two variables. In a bivariate correlation, stipulation that the variables have the grounds and upshot association, they have high extent of connection between them.

Table 1 discloses the correlation between profit after tax (PAT) and corporate social responsibility (CSR) as well as earnings per share (EPS) and corporate social responsibility (CSR). It reveals that profit after tax is negatively somewhat (0.075) connected with corporate social responsibility but this relationship is statistically insignificant at $5 \%$ level. On the other hand other profitability ratio, earnings per share is also meagerly negatively associated (0.09) with corporate social responsibility but this relationship is statistically insignificant at $5 \%$ level. This means the consequence is holding up the confidence that both profitability ratios are inefficiently influence the corporate social responsibility of BHEL.

Table1.Correlation Statistics

\begin{tabular}{|c|c|c|c|}
\hline & CSR & PAT & EPS \\
\hline CSR & 1 & & \\
\hline PAT & $-0.075(0.838)$ & 1 & \\
\hline EPS & $-0.090(0.806)$ & $-0.438(0.206)$ & 1 \\
\hline
\end{tabular}

\subsubsection{Regression test results}

To find out the cause and effect of the relationship between profitability ratios and corporate social responsibility, this study uses a simple and multiple regression analysis. In case of simple regression analysis, profit after tax and earnings per share have been taken separately as dependent variables and corporate social responsibility has been taken as an independent variable. In case of multiple regression analysis, corporate social responsibility has been taken as a dependent variable and both profitability ratios have been taken as independent variables

Table2.Simple Regression between PAT and CSR

\begin{tabular}{|c|c|c|c|c|c|}
\hline Model & & \multicolumn{2}{|c|}{ Unstandardized Coefficients } & $\mathrm{t}$ & Prob. \\
\hline & & B & Std. Error & & \\
\hline 1 & (Constant) & 8.272 & .861 & 9.610 & .000 \\
\hline & CSR & -.053 & .250 & -.211 & .838 \\
\hline
\end{tabular}

A. Dependent Variable: PAT

It is realistic from the above that an increase in PAT by one unit; the CSR decreased by 0.053 unit that were statistically insignificant at 5 per cent level, which is given in table 2. This indicates that CSR of BHEL is affected by other factor, not profitability of the company

Table3.Simple Regression between EPS and CSR

\begin{tabular}{|c|c|c|c|c|c|}
\hline Model & & \multicolumn{2}{|c|}{ Unstandardized Coefficients } & $\mathrm{t}$ & Prob. \\
\hline & & $\mathrm{B}$ & Std. Error & & \\
\hline 1 & (Constant) & 3.677 & .929 & 3.957 & .004 \\
\hline & CSR & -.069 & .270 & -.254 & .806 \\
\hline
\end{tabular}

A. Dependent Variable: EPS

Again, it is practical that an increase in EPS by one unit; the CSR decreased by 0.069 unit that were statistically insignificant at 5 per cent level, which is given in table 3. This indicates that CSR of BHEL is affected by other factor, not profitability of the company

Table4.Multiple Regression

\begin{tabular}{|c|c|c|c|c|c|c|c|}
\hline Model & & Unstandardized Coefficients & $\mathrm{t}$ & Sig. & Collinearity Statistics \\
\hline & & $\mathrm{B}$ & Std. Error & & & & VIF \\
\hline 1 & (Constant) & 5.616 & 5.808 & .967 & .366 & & 1.237 \\
\hline & PAT & -.198 & .585 & -.339 & .745 & \\
\hline & EPS & -.197 & .541 & -.364 & .727 & \multicolumn{3}{c|}{ Adjusted $\mathrm{R}^{2}=-0.255$} \\
\hline & $\mathrm{R}=0.155$ & \multicolumn{2}{|c|}{$\mathrm{R}^{2}=0.024$} & \multicolumn{3}{c|}{ Durbin-Watson $=1.057 ; \mathrm{F}=0.09(0.92)$} \\
\hline
\end{tabular}




\section{American Research Journal of Humanities and Social Sciences, Volume 1, Issue 3, June-2015}

ISSN 2378-7031

\section{A. Dependent Variable: CSR}

The influence of the relationship between the dependent variable, CSR and two independent variables taken together and the impact of these independent variables on the corporate social responsibility are given in table 4 .

It was sensible from the above that an increase in PAT by one unit; the CSR decreased by 0.198 unit that were statistically insignificant at 5 per cent level. When EPS is increased by one unit, the CSR of BHEL is also decreased by 0.197 units that were not significant at $5 \%$ level. It indicates that the corporate social responsibility was little responded by its independent variables. Multiple correlations $(0.155)$ were very low, which indicates that corporate social responsibility and profitability meagerly associated in case BHEL. It is also evident from the value of $\mathrm{R}^{2}$ that 2.4 per cent of variation in CSR was accounted by the joint variation in independent variables. Adjusted $\mathrm{R}^{2}$ shows that negative 2.5 per cent of the variations in the CSR are explained by the independent variables. Standard Error of regression coefficients being not very high discloses that there endures actually line of estimates among the variables. VIF was less than 2 that designates there was no multicollinearity problem. Furthermore Durbin-Watson statistics (1.057) points out those residuals were not serially interrelated. F statistics with profitability designates that the regression model is absolutely fitted. An unimportant inconsistency in corporate social responsibility could be the effect of the joint consequence acknowledged in this study and several other unexplained variables.

\subsection{Empirical results of CIL}

\subsubsection{Correlation statistics}

Table 5 discloses the correlation between profit after tax and corporate social responsibility as well as earnings per share and corporate social responsibility. It divulges that profit after tax is positively somewhat $(0.587)$ connected with corporate social responsibility and this relationship is statistically insignificant at 5\% level. On the other hand other profitability ratio, earnings per share is also positively associated $(0.145)$ with corporate social responsibility but this relationship is statistically insignificant at 5\% level. This means the consequence is holding up the confidence that both profitability ratios are efficiently influence the corporate social responsibility of CIL

Table5.Correlation Statistics

\begin{tabular}{|l|c|c|c|}
\hline & CSR & PAT & EPS \\
\hline CSR & \multicolumn{1}{|c|}{1} & \multicolumn{1}{|c|}{1} & \\
\hline PAT & $.587(.075)$ & \multicolumn{1}{|c|}{1} & \\
\hline EPS & $.145(.689)$ & $.748(.013)$ & 1 \\
\hline
\end{tabular}

\subsubsection{Regression analysis}

It is realistic from the above that an increase in PAT by one unit; the CSR increases by 0.588 unit that were statistically significant at 5 per cent level, which is given in table 6 . This indicates that CSR of CIL is affected by profitability of the company

Table6.Simple Regression between PAT and CSR

\begin{tabular}{|l|c|c|c|c|}
\hline Model & \multicolumn{2}{|c|}{ Unstandardized Coefficients } & t & Prob. \\
\hline & B & Std. Error & & \\
\hline (Constant) & 6.471 & 1.228 & 5.269 & .001 \\
\hline CSR & .588 & .287 & 2.049 & .075 \\
\hline
\end{tabular}

A. Dependable Variable: PAT

Table7.Simple Regression between EPS and CSR

\begin{tabular}{|l|c|c|c|c|}
\hline Model & \multicolumn{2}{|c|}{ Unstandardized Coefficients } & $\mathrm{t}$ & Prob. \\
\hline & $\mathrm{B}$ & Std. Error & & \\
\hline (Constant) & 2.216 & 1.482 & 1.496 & .173 \\
\hline CSR & .144 & .346 & .416 & .689 \\
\hline
\end{tabular}

A. Dependable Variable: EPS

Again, it is practical that an increase in EPS by one unit; the CSR increases by 0.144 unit that were statistically significant at 5 per cent level, which is given in table 7. This indicates that CSR of CIL is affected by EPS i.e. the profitability of the company 
American Research Journal of Humanities and Social Sciences, Volume 1, Issue 3, June-2015 ISSN 2378-7031

Table8. Multiple Regression

\begin{tabular}{|c|c|c|c|c|c|c|c|}
\hline Model & & Unstandardized Coefficients & t & Sig. & Collinearity Statistics \\
\hline & & $\mathrm{B}$ & Std. Error & & & & VIF \\
\hline 1 & (Constant) & -3.564 & 2.735 & -1.303 & .234 & \\
\hline & PAT & 1.083 & .386 & 2.807 & .026 & 2.270 \\
\hline & EPS & -.673 & .391 & -1.724 & .128 & 2.270 \\
\hline & $\mathrm{R}=0.735$ & \multicolumn{2}{c|}{$\mathrm{R}^{2}=0.540$} & \multicolumn{2}{c|}{ Adjusted $\mathrm{R}^{2}=-0.408$} \\
\hline & \multicolumn{2}{|c|}{ Std. Error of the Estimate $=0.50156$} & \multicolumn{2}{c|}{ Durbin-Watson $=2.943 ; \mathrm{F}=0.09(0.92)$} \\
\hline
\end{tabular}

A. Dependable Variable: CSR

The influence of the relationship between the dependent variable, CSR and two independent variables taken together and the impact of these independent variables on the corporate social responsibility are given in table 8 .

It was sensible from the above that an increase in PAT by one unit; the CSR increases by 1.083 unit that were statistically significant at 5 per cent level. When EPS is increased by one unit, the CSR of CIL is also decreased by 0.673 units that were not significant at 5\% level. It indicates that the corporate social responsibility was little responded by its independent variables. Multiple correlations $(0.735)$ were high, which indicates that corporate social responsibility and profitability highly positively associated in case CIL. It is also evident from the value of $\mathrm{R}^{2}$ that 54 per cent of variation in CSR was accounted by the joint variation in independent variables. Adjusted $\mathrm{R}^{2}$ shows that negative 40.8 per cent of the variations in the CSR are explained by the independent variables. Standard Error of regression coefficients being not very high discloses that there endures actually line of estimates among the variables. VIF was less than thumb rule of statistics that designates there was no multicollinearity problem. Furthermore Durbin-Watson statistics (2.943) points out those residuals were not serially interrelated. F statistics with profitability designates that the regression model is absolutely fitted. An unimportant inconsistency in corporate social responsibility could be the effect of the joint consequence acknowledged in this study and several other unexplained variables.

\subsection{Empirical Results of GAIL}

\subsubsection{Correlation statistics}

In general, correlation statistics makes an effort to detect the extent and trend of connection between two variables. In a bivariate correlation, stipulation that the variables have the grounds and upshot association, they have high extent of connection between them.

Table 9 discloses the correlation between profit after tax (PAT) and corporate social responsibility (CSR) as well as earnings per share (EPS) and corporate social responsibility (CSR). It reveals that profit after tax is negatively somewhat $(0.963)$ connected with corporate social responsibility and this relationship is statistically significant at $1 \%$ level. On the other hand other profitability ratio, earnings per share is also positively associated (0.609) with corporate social responsibility and this relationship is statistically insignificant at 5\% level. This means the consequence is holding up the confidence that both profitability ratios are sufficiently influence the corporate social responsibility of GAIL.

Table9. Correlation Statistics

\begin{tabular}{|c|c|c|c|}
\hline & CSR & PAT & EPS \\
\hline CSR & 1 & & \\
\hline PAT & $.963(.000)$ & 1 & 1 \\
\hline EPS & $.609(.062)$ & $.615(.058)$ & 1 \\
\hline
\end{tabular}

\subsubsection{Regression analysis}

It is realistic from the above that an increase in PAT by one unit; the CSR increases by 0.406 unit that were statistically significant at 5 per cent level, which is given in table 10 . This indicates that CSR of GAIL is affected by PAT i.e. profitability of the company

Table10. Simple Regression between PAT and CSR

\begin{tabular}{|c|c|c|c|c|c|}
\hline Model & & \multicolumn{2}{|c|}{ Unstandardized Coefficients } & $\mathrm{t}$ & Prob. \\
\hline & & $\mathrm{B}$ & Std. Error & & \\
\hline 1 & (Constant) & 6.518 & .149 & 43.770 & .000 \\
\hline & CSR & .406 & .040 & 10.093 & .000 \\
\hline
\end{tabular}


American Research Journal of Humanities and Social Sciences, Volume 1, Issue 3, June-2015 ISSN 2378-7031

A. Dependent Variable: PAT

Table11. Simple Regression between EPS and CSR

\begin{tabular}{|l|l|c|c|c|c|}
\hline Model & & \multicolumn{2}{|c|}{ Unstandardized Coefficients } & $\mathrm{t}$ & Prob. \\
\hline & & $\mathrm{B}$ & Std. Error & & \\
\hline 1 & (Constant) & 2.824 & .232 & 12.181 & .000 \\
\hline & CSR & .136 & .063 & 2.171 & .000 \\
\hline
\end{tabular}

A. Dependent Variable: EPS

Again, it is practical that an increase in EPS by one unit; the CSR increases by 0.136 unit that were statistically insignificant at 5 per cent level, which is given in table 11. This indicates that CSR of GAIL is also affected by EPS i.e. profitability of the company

Table - 12.Multiple Regression

\begin{tabular}{|c|c|c|c|c|c|c|c|}
\hline Model & & Unstandardized Coefficients & $\mathrm{t}$ & Sig. & \multicolumn{2}{c|}{ Collinearity Statistics } \\
\hline & & $\mathrm{B}$ & Std. Error & & & & VIF \\
\hline 1 & Constant $)$ & -14.691 & 1.972 & -7.449 & .000 & & 1.609 \\
\hline & PAT & 2.243 & .306 & 7.340 & .000 & & 1.609 \\
\hline & EPS & .120 & .577 & .207 & .842 & \multicolumn{3}{c|}{ Adjusted $\mathrm{R}^{2}=-0.907$} \\
\hline & $\mathrm{R}=0.963$ & \multicolumn{2}{|c|}{$\mathrm{R}^{2}=0.928$} & \multicolumn{3}{c|}{ Durbin-Watson $=1.809 ; \mathrm{F}=0.09(0.92)$} \\
\hline
\end{tabular}

\section{A. Dependent Variable: CSR}

The influence of the relationship between the dependent variable, CSR and two independent variables taken together and the impact of these independent variables on the corporate social responsibility are given in table 12 . It was sensible from the above that an increase in PAT by one unit; the CSR increases by 2.243 unit that were statistically significant at 1 per cent level. When EPS is increased by one unit, the CSR of GAIL is also increased by 0.120 units that were significant at $1 \%$ level. It indicates that the corporate social responsibility was little responded by its independent variables. Multiple correlations (0.963) were very high, which indicates that corporate social responsibility and profitability highly associated in case GAIL. It is also evident from the value of $\mathrm{R}^{2}$ that 92.8 per cent of variation in CSR was accounted by the joint variation in independent variables. Adjusted $\mathrm{R}^{2}$ shows that negative 90.7 per cent of the variations in the CSR are explained by the independent variables. Standard Error of regression coefficients being not very high discloses that there endures actually line of estimates among the variables. VIF was less than 2 that designates there was no multicollinearity problem. Furthermore Durbin-Watson statistics (1.809) points out those residuals were not serially interrelated. F statistics with profitability designates that the regression model is absolutely fitted. An unimportant inconsistency in corporate social responsibility could be the effect of the joint consequence acknowledged in this study and several other unexplained variables.

\subsection{Empirical Results of IOCL}

\subsubsection{Correlation Statistics}

In general, correlation statistics makes an effort to detect the extent and trend of connection between two variables. In a bivariate correlation, stipulation that the variables have the grounds and upshot association, they have high extent of connection between them.

Table 13 discloses the correlation between profit after tax (PAT) and corporate social responsibility (CSR) as well as earnings per share (EPS) and corporate social responsibility (CSR). It reveals that profit after tax is negatively somewhat (0.454) connected with corporate social responsibility but this relationship is statistically insignificant at $5 \%$ level. On the other hand other profitability ratio, earnings per share is also meagerly negatively associated (0.327) with corporate social responsibility but this relationship is statistically insignificant at $5 \%$ level. This means the consequence is holding up the confidence that both profitability ratios are inefficiently influence the corporate social responsibility of IOCL.

Table13.Correlation Statistics

\begin{tabular}{|c|c|c|c|}
\hline & CSR & PAT & EPS \\
\hline CSR & & & \\
\hline PAT & $.454(.187)$ & 1 & \\
\hline EPS & $-.327(.356)$ & $.575(.082)$ & 1 \\
\hline
\end{tabular}


American Research Journal of Humanities and Social Sciences, Volume 1, Issue 3, June-2015 ISSN 2378-7031

\subsubsection{Regression analysis of IOCL}

Table14. Simple Regression between PAT and CSR

\begin{tabular}{|c|c|c|c|c|c|}
\hline Model & & \multicolumn{2}{|c|}{ Unstandardized Coefficients } & $\mathrm{t}$ & Prob. \\
\hline & & $\mathrm{B}$ & Std. Error & & \\
\hline 1 & (Constant) & 10.988 & 1.620 & 6.783 & .000 \\
\hline & CSR & -.530 & .367 & -1.443 & .187 \\
\hline
\end{tabular}

A. Dependent Variable: PAT

It is realistic from the above that an increase in PAT by one unit; the CSR decreased by 0.053 unit that were statistically insignificant at 5 per cent level, which is given in table 14. This indicates that CSR of IOCL is affected by other factor, not profitability of the company

Table15. Simple Regression between EPS and CSR

\begin{tabular}{|l|l|r|r|r|r|}
\hline Model & & \multicolumn{2}{|c|}{ Unstandardized Coefficients } & \multicolumn{1}{c|}{$\mathrm{t}$} & \multicolumn{1}{c|}{ Prob. } \\
\hline & & B & Std. Error & & \\
\hline 1 & (Constant) & 5.548 & 2.073 & 2.676 & .028 \\
\hline & CSR & -.460 & .470 & -.979 & .356 \\
\hline
\end{tabular}

A. Dependent Variable: EPS

Again, it is practical that an increase in EPS by one unit; the CSR decreased by 0.460 unit that were statistically insignificant at 5 per cent level, which is given in table 15. This indicates that CSR of IOCL is affected by other factor, not profitability of the company

Table16. Multiple Regression

\begin{tabular}{|c|c|c|c|c|c|c|c|}
\hline Model & & Unstandardized Coefficients & $\mathrm{t}$ & Sig. & Collinearity Statistics \\
\hline & & $\mathrm{B}$ & Std. Error & & & & VIF \\
\hline 1 & (Constant) & 7.600 & 2.594 & .2 .930 & .022 & & 1.494 \\
\hline & PAT & -.341 & .351 & -.971 & .364 & & 1.494 \\
\hline & EPS & -.070 & .291 & -.240 & .817 & \multicolumn{3}{c|}{ Adjusted $\mathrm{R}^{2}=-0.012$} \\
\hline & $\mathrm{R}=0.462$ & \multicolumn{2}{|c|}{$\mathrm{R}^{2}=0.213$} & \multicolumn{3}{c|}{ Durbin-Watson $=2.737 ; \mathrm{F}=0.09(0.92)$} \\
\hline
\end{tabular}

\section{A. Dependent Variable: CSR}

The influence of the relationship between the dependent variable, CSR and two independent variables taken together and the impact of these independent variables on the corporate social responsibility are given in table 16 . It was sensible from the above that an increase in PAT by one unit; the CSR decreased by 0.341 unit that were statistically insignificant at 5 per cent level. When EPS is increased by one unit, the CSR of IOCL is also decreased by 0.070 units that were not significant at $5 \%$ level. It indicates that the corporate social responsibility was little responded by its independent variables. Multiple correlations (0.462) were moderate, which indicates that corporate social responsibility and profitability meagerly associated in case IOCL. It is also evident from the value of $\mathrm{R}^{2}$ that 21.3 per cent of variation in CSR was accounted by the joint variation in independent variables. Adjusted $\mathrm{R}^{2}$ shows that negative 1.2 per cent of the variations in the CSR are explained by the independent variables. Standard Error of regression coefficients being not very high discloses that there endures actually line of estimates among the variables. VIF was less than 2 that designates there was no multicollinearity problem. Furthermore Durbin-Watson statistics (2.737) points out those residuals were not serially interrelated. F statistics with profitability designates that the regression model is absolutely fitted. An unimportant inconsistency in corporate social responsibility could be the effect of the joint consequence acknowledged in this study and several other unexplained variables

\subsection{Empirical results of NTPC}

\subsubsection{Correlation statistics}

In general, correlation statistics makes an effort to detect the extent and trend of connection between two variables. In a bivariate correlation, stipulation that the variables have the grounds and upshot association, they have high extent of connection between them. Table 17 discloses the correlation between profit after tax (PAT) and corporate social responsibility (CSR) as well as earnings per share (EPS) and corporate social responsibility (CSR). It reveals 


\section{American Research Journal of Humanities and Social Sciences, Volume 1, Issue 3, June-2015}

ISSN 2378-7031

that profit after tax is positively somewhat (0.535) connected with corporate social responsibility but this relationship is statistically insignificant at $1 \%$ level. On the other hand other profitability ratio, earnings per share is also positively associated (0.509) with corporate social responsibility but this relationship is statistically insignificant at $1 \%$ level. This means the consequence is holding up the confidence that both profitability ratios are efficiently influence the corporate social responsibility of NTPC.

Table17. Correlation Statistics

\begin{tabular}{|l|c|c|c|}
\hline & CSR & PAT & EPS \\
\hline CSR & 1 & & \\
\hline PAT & $.535(.109)$ & 1 & 1 \\
\hline EPS & $.509(.133)$ & $.999(.000)$ & \\
\hline
\end{tabular}

\subsubsection{Regression analysis of NTPC}

Table18.Simple Regression between PAT and CSR

\begin{tabular}{|l|l|r|r|r|r|r|}
\hline Model & & \multicolumn{2}{|c|}{ Unstandardized Coefficients } & \multicolumn{2}{c|}{$\mathrm{t}$} & \multicolumn{2}{c|}{ Prob. } \\
\hline & & B & Std. Error & .156 & 56.058 & .000 \\
\hline 1 & (Constant) & 8.766 & & .156 & 1.802 & .109 \\
\hline
\end{tabular}

\section{A. Dependent Variable: PAT}

It is realistic from the above that an increase in PAT by one unit; the CSR increased by 0.068 unit that were statistically insignificant at 5 per cent level, which is given in table 18. This indicates that CSR of NTPC is affected by PAT i.e. profitability of the company

Table19. Simple Regression between EPS and CSR

\begin{tabular}{|l|l|c|c|c|c|}
\hline Model & & \multicolumn{2}{|c|}{ Unstandardized Coefficients } & $\mathrm{t}$ & Prob. \\
\hline & & $\mathrm{B}$ & Std. Error & & \\
\hline 1 & (Constant) & 2.071 & .157 & 13.221 & .000 \\
\hline & CSR & .063 & .038 & 1.673 & .133 \\
\hline
\end{tabular}

\section{A. Dependent Variable: EPS}

Again, it is practical that an increase in EPS by one unit; the CSR is increased by 0.063 unit that were statistically significant at 1 per cent level, which is given in table 19. This indicates that CSR of NTPC is affected by EPS i.e. the profitability of the company.

Table20. Multiple Regression

\begin{tabular}{|c|c|c|c|c|c|c|c|}
\hline Model & & Unstandardized Coefficients & $\mathrm{t}$ & Sig. & Collinearity Statistics \\
\hline & & $\mathrm{B}$ & Std. Error & & & & VIF \\
\hline 1 & (Constant) & 754.071 & 5.687 & -6.235 & .000 & \\
\hline & PAT & 133.33 & 2.004 & 1.972 & .000 & 2.004 \\
\hline & EPS & -74.599 & 1.487 & -1.420 & .000 & 1.983 \\
\hline & $\mathrm{R}=0.595$ & \multicolumn{2}{c|}{ Adjusted $\mathrm{R}^{2}=0.492$} \\
\hline & \multicolumn{2}{|c|}{ Std. Error of the Estimate $=1.284$} & \multicolumn{3}{c|}{ Durbin-Watson $=2.323 ; \mathrm{F}=1.58(0.64)$} \\
\hline
\end{tabular}

A. Dependent Variable: CSR

The influence of the relationship between the dependent variable, CSR and two independent variables taken together and the impact of these independent variables on the corporate social responsibility are given in table 20. It was sensible from the above that an increase in PAT by one unit; the CSR is increased by 133.33 units that were statistically significant at $1 \%$ level. When EPS is increased by one unit, the CSR of NTPC is also is decreased by 74.599 units that were statistically significant at $1 \%$ level. It indicates that the corporate social responsibility was responded high by its independent variables. Multiple correlations $(0.595)$ were proper, which indicates that corporate social responsibility and profitability particularly associated in case IOCL. It is moreover apparent from the value of $\mathrm{R}^{2}$ that 52.1 per cent of variation in CSR was accounted by the joint variation in independent variables. Adjusted $\mathrm{R}^{2}$ shows that negative 49.2 per cent of the variations in the CSR are explained by the independent 


\section{American Research Journal of Humanities and Social Sciences, Volume 1, Issue 3, June-2015}

ISSN 2378-7031

variables. Standard Error of regression coefficients being not very high discloses that there tolerates actually line of estimates among the variables. VIF was more or less 2 that designates there was no multicollinearity problem. Furthermore Durbin-Watson statistics (2.323) points out those residuals were not serially interrelated. F statistics with profitability designates that the regression model is absolutely fitted. An inconsequential contradiction in corporate social responsibility could be the outcome of the combined effect recognized in this study and numerous other unexplained variables.

\subsection{Empirical Results of ONGC}

\subsubsection{Correlation Statistics}

In general, correlation statistics makes an effort to detect the extent and trend of connection between two variables. In a bivariate correlation, stipulation that the variables have the grounds and upshot association, they have high extent of connection between them. Table 21 discloses the correlation between profit after tax (PAT) and corporate social responsibility (CSR) as well as earnings per share (EPS) and corporate social responsibility (CSR). It reveals that profit after tax is negatively somewhat $(0.015)$ connected with corporate social responsibility but this relationship is statistically insignificant at $1 \%$ level. On the other hand other profitability ratio, earnings per share is somehow positively associated (0.040) with corporate social responsibility and this relationship is statistically significant at $1 \%$ level. This means the consequence is holding up the confidence that out of two profitability ratios one is inefficiently and one is sufficiently influence the corporate social responsibility of ONGC.

Table - 21.Correlation Statistics

\begin{tabular}{|c|c|c|c|}
\hline & CSR & PAT & EPS \\
\hline CSR & 1 & & \\
\hline PAT & $-.015(.967)$ & 1 & \\
\hline EPS & $.040(.913)$ & $.981(.000)$ & 1 \\
\hline
\end{tabular}

\subsubsection{Regression analysis of ONGC}

To find out the cause and effect of the relationship between profitability ratios and corporate social responsibility, this study uses a simple and multiple regression analysis. In case of simple regression analysis, profit after tax and earnings per share have been taken separately as dependent variables and corporate social responsibility has been taken as an independent variable. In case of multiple regression analysis, corporate social responsibility has been taken as a dependent variable and both profitability ratios have been taken as independent variables.

Table - 22.Simple Regression between PAT and CSR

\begin{tabular}{|c|c|c|c|c|c|}
\hline Model & & \multicolumn{2}{|c|}{ Unstandardized Coefficients } & $\mathrm{t}$ & Prob. \\
\hline & & $\mathrm{B}$ & Std. Error & & \\
\hline 1 & (Constant) & 9.788 & .537 & 18.239 & .000 \\
\hline & CSR & -.005 & .110 & -.043 & .967 \\
\hline
\end{tabular}

A. Dependent Variable: PAT

It is realistic from the above that an increase in PAT by one unit; the CSR decreased by 0.005 unit that were statistically insignificant at 1 per cent level, which is given in table 22. This indicates that CSR of ONGC is affected by other factor, not profitability of the company

Table - 23.Simple Regression between EPS and CSR

\begin{tabular}{|c|c|c|c|c|c|}
\hline Model & & \multicolumn{2}{|c|}{ Unstandardized Coefficients } & $\mathrm{t}$ & Prob. \\
\hline & & B & Std. Error & & \\
\hline 1 & (Constant) & 2.965 & .539 & 5.504 & .001 \\
\hline & CSR & .012 & .110 & .113 & 913 \\
\hline
\end{tabular}

A. Dependent Variable: EPS

Again, it is practical that an increase in EPS by one unit; the CSR is increased by 0.012 unit that were statistically significant at 1 per cent level, which is given in table 23. This indicates that CSR of ONGC is affected by EPS i.e. the profitability of the company. 
American Research Journal of Humanities and Social Sciences, Volume 1, Issue 3, June-2015 ISSN 2378-7031

Table24. Multiple Regression

\begin{tabular}{|c|c|c|c|c|c|c|c|}
\hline Model & & \multicolumn{2}{|c|}{ Unstandardized Coefficients } & $\mathrm{t}$ & Sig. & Collinearity Statistics \\
\hline & & $\mathrm{B}$ & Std. Error & & & & VIF \\
\hline 1 & (Constant) & 37.085 & 41.624 & .891 & .403 & & 2.7223 \\
\hline & PAT & -4.790 & 6.091 & -.786 & .457 & & 2.7223 \\
\hline & EPS & 4.809 & 6.064 & .793 & .454 & \multicolumn{5}{c|}{ Adjusted $\mathrm{R}^{2}=0.3101$} \\
\hline & $\mathrm{R}=0.445$ & \multicolumn{2}{|c|}{$\mathrm{R}^{2}=0.398$} & \multicolumn{4}{c|}{ Durbin-Watson $=1.915 ; \mathrm{F}=2.14(0.14)$} \\
\hline
\end{tabular}

A. Dependent Variable: CSR

The influence of the relationship between the dependent variable, CSR and two independent variables taken together and the impact of these independent variables on the corporate social responsibility are given in table 24 . It was sensible from the above that an increase in PAT by one unit; the CSR decreased by 4.790 unit that were statistically insignificant at 1 per cent level. When EPS is increased by one unit, the CSR of ONGC is increased by 4.809 units that were significant at $1 \%$ level. It indicates that the corporate social responsibility was little responded by its independent variables. Multiple correlations (0.445) were low, which indicates that corporate social responsibility and profitability associated in case ONGC. It is furthermore obvious from the value of $\mathrm{R}^{2}$ that 39.8 per cent of variation in CSR was accounted by the joint variation in independent variables. Adjusted $\mathrm{R}^{2}$ shows that 31.01 per cent of the variations in the CSR are explained by the independent variables. Standard Error of regression coefficients being not very high that divulges that there continues really line of estimates among the variables. VIF was less than thumb rule that assigns there was no multicollinearity problem. In addition Durbin-Watson statistics (1.915) points out those residuals were not serially interrelated. F statistics with profitability allocates that the regression model is extremely fitted. A slight unpredictability in corporate social responsibility could be the upshot of the mutual corollary accredited in this study and a number of other unexplained variables.

\subsection{Empirical results of SAIL}

\subsubsection{Correlation statistics}

In general, correlation statistics makes an effort to detect the extent and trend of connection between two variables. In a bivariate correlation, stipulation that the variables have the grounds and upshot association, they have high extent of connection between them. Table 25 discloses the correlation between profit after tax (PAT) and corporate social responsibility (CSR) as well as earnings per share (EPS) and corporate social responsibility (CSR). It reveals that profit after tax is positively somewhat (.020) connected with corporate social responsibility and this relationship is statistically insignificant at $1 \%$ level. On the other hand other profitability ratio, earnings per share is also meagerly negatively associated (0.020) with corporate social responsibility but this relationship is statistically insignificant at $1 \%$ level. This means the consequence is holding up the confidence that both profitability ratios are efficiently influence the corporate social responsibility of SAIL.

Table25. Correlation Statistics

\begin{tabular}{|c|c|c|c|}
\hline & CSR & PAT & EPS \\
\hline CSR & 1 & & \\
\hline PAT & $.020(.957)$ & 1 & \\
\hline EPS & $.020(.957)$ & $1.000(.000)$ & 1 \\
\hline
\end{tabular}

\subsubsection{Regression analysis}

To find out the cause and effect of the relationship between profitability ratios and corporate social responsibility, this study uses a simple and multiple regression analysis. In case of simple regression analysis, profit after tax and earnings per share have been taken separately as dependent variables and corporate social responsibility has been taken as an independent variable. In case of multiple regression analysis, corporate social responsibility has been taken as a dependent variable and both profitability ratios have been taken as independent variables

Table26. Simple Regression between PAT and CSR

\begin{tabular}{|c|c|c|c|c|c|}
\hline Model & & \multicolumn{2}{|c|}{ Unstandardized Coefficients } & $\mathrm{t}$ & Prob. \\
\hline & & B & Std. Error & & \\
\hline 1 & (Constant) & 8.390 & 1.175 & 7.141 & .000 \\
\hline & CSR & .016 & .292 & .056 & .957 \\
\hline
\end{tabular}


American Research Journal of Humanities and Social Sciences, Volume 1, Issue 3, June-2015 ISSN 2378-7031

\section{A. Dependent Variable: PAT}

It is realistic from the above that an increase in PAT by one unit; the CSR increased by 0.016unit that were statistically significant at 1 per cent level, which is given in table 26. This indicates that CSR of SAIL is affected by PAT i.e. profitability of the company

Table27. Simple Regression between EPS and CSR

\begin{tabular}{|c|c|c|c|c|c|}
\hline Model & & \multicolumn{2}{|c|}{ Unstandardized Coefficients } & $\mathrm{t}$ & Prob. \\
\hline & & $\mathrm{B}$ & Std. Error & & \\
\hline 1 & (Constant) & 2.367 & 1.171 & 2.021 & .078 \\
\hline & CSR & .016 & .291 & .056 & .957 \\
\hline
\end{tabular}

A. Dependent Variable: EPS

Again, it is practical that an increase in EPS by one unit; the CSR is increased by 0.016 unit that were statistically significant at 1 per cent level, which is given in table 27. This indicates that CSR of SAIL is affected by EPS i.e. profitability of the company

Table28. Multiple Regression

\begin{tabular}{|c|c|c|c|c|c|c|}
\hline Model & & \multicolumn{2}{|c|}{ Unstandardized Coefficients } & $\mathrm{t}$ & Sig. & Collinearity Statistics \\
\hline & & $\mathrm{B}$ & Std. Errol & & & VIF \\
\hline \multirow[t]{4}{*}{1} & (Constant) & 3.935 & 1.059 & 3.716 & .006 & \\
\hline & EPS & .024 & .429 & .056 & .957 & 1.0022 \\
\hline & $\mathrm{R}=0.020$ & \multicolumn{2}{|c|}{$\mathrm{R}^{2}=0.0001$} & \multicolumn{3}{|c|}{ Adjusted $\mathrm{R}^{2}=-.125$} \\
\hline & \multicolumn{3}{|c|}{ of the Estimate $=0.55663$} & \multicolumn{3}{|c|}{ Durbin-Watson $=1.489 ; \mathrm{F}=0.09(0.92)$} \\
\hline
\end{tabular}

\section{A. Dependent Variable: CSR}

The influence of the relationship between the dependent variable, CSR and two independent variables taken together and the shock of these independent variables on the corporate social responsibility are given in table 28. It is very much important that PAT has been removed before calculation from the model. But when EPS is increased by one unit, the CSR of SAIL is increased by 0.024 units that were not significant at 5\% level. It indicates that the corporate social responsibility was little responded by EPS. Multiple correlations (0.020) were very low, which indicates that corporate social responsibility and profitability scantily associated in case SAIL. It is also evident from the value of $\mathrm{R}^{2}$ that 0.01 per cent of variation in CSR was accounted by the joint variation in independent variables. Adjusted $\mathrm{R}^{2}$ shows that negative 12.5 per cent of the variations in the CSR are explained by the independent variables. Standard Error of regression coefficients being very high discloses that there suffers actually line of estimates among the variables. VIF was less than 2 that designates there was no multicollinearity problem. Furthermore Durbin-Watson statistics (1.489) points out those residuals were not serially interrelated. F statistics with profitability designates that the regression model is extremely fitted. An inconsequential changeability in corporate social responsibility could be the outcome of the common effect accepted in this study and quite a lot of other unexplained variables.

\section{CONCLUSIONS}

The crucial findings of the study is that profit after tax is negatively associated with corporate social responsibility in case of BHEL, IOCL and ONGC but this relationship is positively associated with CIL, GAIL, NTPC and SAIL. On the other hand other profitability ratio, earnings per share is negatively associated with corporate social responsibility in case of BHEL and IOCL but this relationship is positively associated with CIL, ONGC, GAIL, NTPC and SAIL. Simple regression analysis also shows that profit after tax is negatively associated with corporate social responsibility in case of BHEL, IOCL and ONGC. At the same time, this relationship is positively associated with CIL, GAIL, NTPC and SAIL. Again, simple regression analysis furthermore demonstrate that earnings per share is negatively associated with corporate social responsibility in case of BHEL and IOCL but this relationship is positively associated with CIL, ONGC, GAIL, NTPC and SAIL. When we have considered CSR as a dependent variable and two profitability indicators as independent variables, after considering multiple regressions, these test results confirm that corporate social responsibility is associated negatively with profit after tax and earnings per share in case of BHEL and IOCL. However, corporate social responsibility is associated positively with profit after tax and earnings per share in case of GAIL only. Moreover, multiple regressions test results illustrate that corporate social responsibility is associated dramatically in an alternative way in case of CIL, NTPC and SAIL. 


\section{American Research Journal of Humanities and Social Sciences, Volume 1, Issue 3, June-2015 ISSN 2378-7031}

These findings are very much important for the Indian corporate sector because when corporate social responsibility expenditures are increased, profitability of BHEL and IOCL have been decreased in a significant manner and also for CIL, NTPC and SAIL. But this result is different and positive in case of GAIL where profitability has been increased in spite of increase of CSR expenditures. This is a positive indication for the Indian society.

This study is not free from certain limitations because this study considers only seven Maharatna Companies in India for ten years period. Therefore, there is a huge scope for further research. This study may be improved if all the central public sector enterprises in India are considered. This may be our future study

\section{REFERENCES}

[1] Das, Kanti. Bidhu and Halder, P.K. (2011). Corporate Social Responsibility Initiatives of Oils PSUs in Assam: A Case Study of ONGC. Management Convergence, 2(2), 75-85.

[2] Lech, Aleksandra. (2013). Corporate Social Responsibility and Financial Performance. Theoretical and Empirical Aspects. Available at www.degruyter.com. Retrieved on 30.4.2015.

[3] Kim, Jinwook; Chung, Sunggon and Park, Cheongkyu. (2013). Corporate Social Responsibility and Financial Performance: The Impact of MSCI ESG Rating on Korean Firms. Journal of the Korea Academia- Industrial Cooperation Society, 14(11), 5586-5593.

[4] Kanwal, Munaza; Khanam, Farida; Nasreen, Shagufta and Hameed, Shahid. (2013). Impact of Corporate Social Responsibility on the Firm's Financial Performance. IOSR Journal of Business and Management (IOSR- JBM), 14(5), 6774.

[5] John, Enahoro., John, Akinyomi and E, A. Olutoye. (2013). Corporate social responsibility and financial performance: Evidence from Nigerien manufacturing sector. Asian Journal of Management Research, 4(1), 153-162

[6] Mwangi, Iraya. Cyrus and Jerotich, Jane. Oyenje. (2013). The Relationship between Corporate Social Responsibility Practices and Financial Performance of Firms in the Manufacturing, Constructions and Allied Sector of the Nairobi Securities Exchange. International Journal of Business, Humanities and Technology, 3(2), 81-90.

[7] Kumar, Pradeep, N.K and Reddy, Mohan. P. (2014). Corporate Social Responsibility Practices in Steel Authority of India Limited- A Study. IOSR Journal of Humanities and Social Science, 41-46.

[8] Gupta, L. Kalpeshkumar and Arora, Rachna. (2014). Study of Corporate Social Responsibility in the Central Public Sector Enterprises of India. Available at http://www.academia.edu/6138096/Corporate_Social_Responsibility_in_Public_Sector_Enterprises_in_India. Retrieved on 20.6.2015.

[9] Singh, Sruti. (2014). Impact of Corporate Social Responsibility and Financial Performance of Firms in UK. Taken online from http://essay.utwente.nl/65014/1/Singh_MA_MB.pdf.

[10] Ikharehon, Idialu. Julius. (2014). The Impact of Corporate Social Responsibility on Firm's Profitability in Nigeria: A Study of Selected Quoted Firms from 2003-2012, International Journal of Management Studies, 1(1), 22-30.

[11] Ofori, Daniel. F; Nyuur, Richard. B and S-Darko, Mildred. D. (2014). Corporate social responsibility and financial performance: fact or fiction? A look at Ghanaian banks. Acta Commercii, 14(1), 1-11.

[12] Hirigoyan, Gerard and Rehm, Poulian. Thierry. (2014). Relationships between Corporate Social Responsibility and Financial Performance: What is the Causality? Electronic copy available at http://ssrn.com/abstruct= 2531631.

[13] Ciciretti, Rocco; Kobeissi, Nada and Zhu, Yun. (2014). Corporate Social Responsibility and Financial Performance: An Analysis of Bank Community. International Journal of Banking, Accunting and Finance. 5(4), 342-373.

[14] Allen,Lauren. (2014).Corporate Social Responsibility and Financial Performance in Consumer and Nonconsumer Sectors. CMC Senior Theses. Paper 8SS. Available at http://scholaership.claremont.edu/cmc-theses/8ss.

[15] Murtaza, Ali. Iqra; Akhtar, Naeem ; Ijaz, Aqsa and Sadiqa, Ayesha. (2014). Impact of Corporate Social Responsibility on Firm Financial Performance: A case Study of Pakistan. Internal Review of Management and Business Research, 3(4), 1914-1927.

[16] Pan, Xiping; Sha, Jinghua; Zhang, Hongliang and Ke, Wenlen. (2014). Relationship between Corporate Social Responsibility and Financial Performance in the Mineral Industry: Evidence from Chinese Mineral Firms. Sustainability, 6, 4077-4701.

[17] Ahamed, Wan, suhazeli. Wan., Almsafir, Khalid. Mahmoudn and Al-Smadi, Walid. Akran (2014). Does Corporate Social Responsibility Lead to Improve in Form Financial Performance? Evidence from Malaysia. International Journal of Economics and Finance, 6(3), 126-138.

[18] Iqbal, Danish; Sarwat, Salman; Baloch, Akhtar. Dr. and Salim, Uzma. (2014). To Be Responsible Socially Viable Financially. European Scientific Journal. 10(28), 427-447. 
[19] Folajin, Oyetayo.O; Ibitoye, Oluwaseun. T and Dunsin, A.T. (2014). Corporate Social Responsibility and Organisational Profitability: An Empirical Investigation of United Bank of Africa (UBA) Plc. International Journal of Academic Research in Business and Social Science. 4(8), 205-214.

[20] Athma, Prashanta and Yarragorla, Narender. (2015). CSR Guidelines: CPSE Vs. Companies Act 2013 ( A Case Study of Maharatna Companies). Available at www.icaindia.info/.../Athma_-_CSR_Guidelines_-_CPSE_Vs_Companies. Retrieved on 20.06.2015.

[21] Fu, Yu-jin and Shen, Ju-qin. (2015). Correlation Analysis between Corporate Social Responsibility and Financial Performance of Chinese Food- processing Enterprises. Advanced journal of Food Science and Technology, 7(11), 850-856.

[22] Babalola, Y. A. (2012). The Impact of Corporate Social Responsibility on Firms' Profitability in Nigeria, European Journal of Economics, Finance and Administrative Sciences, 45, 39-51.

[23] Kiran, S., Kakakhel, S. J. and Shaheen, F. (2015). Corporate Social Responsibility and Firm Profitability: A Case of Oil and Gas Sector of Pakistan, City University Research Journal, 5(1), 110-119. 